\title{
HIGH MOISTURE ACID SULPHATE SOIL EFFECTS ON REED CANARY GRASS
}

\author{
Epie Kenedy Etone ${ }^{1}$, Seija Virtanen ${ }^{2}$, Asko Simojoki ${ }^{2}$ and Frederick Stoddard ${ }^{1}$ \\ ${ }^{1}$ Department of Agricultural Sciences and ${ }^{2}$ Department of Food and Environmental Sciences, University of \\ Helsinki, P.O. Box 27, FI-00014 University of Helsinki, Finland, \\ Email: epie.kenedy@helsinki.fi
}

\begin{abstract}
To examine the suitability of acid sulphate soils for perennial energy cropping and specifically to provide information on the responses of reed canary grass (Phalaris arundinacea L.) to raised water levels, a management option for these problematic soils, large core lysimeters of undisturbed field acid sulphate soil were taken into PVC tubes equipped with ground water level control and measurement instruments, planted with reed canary grass, and studied during the period 2008 - 2011. Two treatments; high water content (HWC, $20 \mathrm{~cm}$ below soil surface) and low water content (LWC, $70 \mathrm{~cm}$ below soil surface, considered normal for acid sulphate soils) were considered and there were 4 replicates. Tiller height, net photosynthesis, and above ground biomass at harvest were measured and $\mathrm{Al}, \mathrm{Fe}, \mathrm{K}, \mathrm{Si}$ and $\mathrm{S}$ were analysed using ICP-OES. Tillers in HWC lysimeters were 30 and $23 \%$ taller than those in LWC lysimeters $(\mathrm{P}=0.003, \mathrm{P}=0.002)$ in September 2009 and 2010 respectively. Net photosynthesis was higher in LWC grasses, although the margin was significant only in year $2009(\mathrm{P}=0.04)$. Spring 2009 , dry matter yields were almost the same in both treatments, but in 2010 and 2011, HWC grasses yielded $43 \%$ and $37 \%$ more than LWC (P $=0.001$ in both years), respectively. Dry matter harvested in spring of both 2010 and 2011 contained more Al, K, S and Si in the LWC treatment than in HWC treatment, whereas the concentration of Fe was higher in HWC treatment in 2009 and 2010. It was concluded that reed canary grass, an established bioenergy crop, grows well in acid sulphate soils and can perform better when the water table is raised to reduce acidity and prevent environmental hazards. This could serve as management option and a solution to the problems cause by acid sulphate soils and same time reduce the controversy about the use of bioenergy crops on arable land.
\end{abstract}

Key words: Reed canary grass, acid sulphate soils, bioenergy, biomass, element composition

\section{Introduction}


The use of cropland for bioenergy production is increasing and remains a very controversial issue. Problematic soils such as acid sulphate soils (a.s.soils hereafter) could be used to grow energy crops and this may help to defuse food versus fuel competition for arable farmland and provide biomass feedstock for energy purposes. To effectively use these soils, the water content could be raised so as to reduce acidity and serve as a management option of these soils. Acid sulphate soils, occupies up to about 300,000 ha of land in Finland (Yli-Halla et al., 1999) and up to about 500,000 ha corresponding to a fourth of all arable land in Finland could be used for energy crop production (Vaino-Mattila et al. 2005). If global food production needs to double before the year 2050 (Braun et al., 2005), it is therefore questionable whether so much land be taken out of food and feed production. With so much marginal and problematic land lying fallow, there is need to make them productive.

Acid sulphate soils contain iron sulphides, the most common being pyrite and are problematic because when exposed to air after being disturbed (draining and liming after annual cropping), the reduced sulphur compounds in the subsoil oxidize to sulphuric acid leading to the release of large quantities of aluminium, iron and other metals from the soil matrix (Dent, 1986). Intense rainfall triggers localized mobilization of acid as runoff into water bodies. In Finland, discharge waters from cultivated a.s.soils have reduced water quality downstream (Astrom, 2005). The acidic leachates are either lethal to aquatic life or at least impair fish reproduction (Hudd and Leskelä, 1988). Other ecological and health effects such as habitat degradation, poor plant productivity and human diseases have been reported. According to Ward et al. (2004), a high water table may keep the sulphur compounds in a.s.soils submerged and prevent their oxidation to sulphuric acid, or even return the oxidized and acidified soil horizons to anoxia and reducing conditions, thereby reducing acidic leachates. A study at the University of Helsinki (Virtanen et al, 2011) also showed that a high water table caused reducing conditions in a.s.soils although it led to increased concentrations of Fe. With this management option, a.s.soils can be used to grow perennial bioenergy crops that require minimal soil disturbance once established. Besides helping to lower dependence on fossil fuel, perennial crops grown in acid sulphate soils that are managed by raised water tables would help reduce environmental and health problems caused by these soils and maintain healthy river ecology. This could sequester carbon in the root zones (Robertson et al., 2008) and reduce greenhouse gases, and serve as an important new source of income for farmers.

Reed canary grass (RCG) (Phalaris arundinacea), a perennial C3 grass was chosen as the crop to be studied because it is indigenous and already used as a bioenergy crop in Finland and Northern Europe (Lewandowski et al., 2003), it is not a food crop, and the dry biomass has good combustion quality and can be harvested once a year at various times (Pahkala and Pihala, 2000). Studies with warm season C4 grasses show they can grow where soil acidity is a problem for conventional cropping systems. Eastern gamma grass was not inhibited by low soil pH and high Al-toxicity of acid soils (Gilker et al. 2002). Unfortunately, there is little or no information the ability of RCG to tolerate a.s. soil, its metal ion content, or high water table. The aim of this study is to examine the suitability of a.s. soils for perennial energy cropping and to provide information on the response of reed canary grass to raised water levels, a management option for the soils.

\section{Materials and Methods}

Eight large core lysimeters made of PVC tubes (height $1.0 \mathrm{~m}$, diameter $0.5 \mathrm{~m}$, sealed from the bottom) were filled with undisturbed acid sulphate soil, classified as a Sulfic Cryaquepts (Yli-Halla 2008, Mokma et al. 2000), taken from Viikki experimental farm of the University of Helsinki, southern Finland $\left(60^{\circ} 13.4^{\prime} \mathrm{N}\right.$, $25^{\circ} 0$ ' E). Virtanen et al. (2010) described these soils as having a B horizon of acid sulphate soil and a transition horizon (BC) located at the depth of the subsurface drainage pipes, about $1 \mathrm{~m}$ below soil surface, followed by a constantly water-logged reduced $\mathrm{C}$ horizon (potential acid sulphate soil). The soil-filled lysimeters, equipped with ground water level control and other measurement instruments, were placed in an outdoor greenhouse compartment with glass roof and planted with reed canary grass turf. There were two treatments, high water content (HWC, $20 \mathrm{~cm}$ below soil surface) and low water content (LWC, $70 \mathrm{~cm}$ below soil surface) and considered normal for agriculturally managed a.s.soil, in four replicates, completely randomised. Treatments were effected in the month of May. Each year, lysimeters were fertilised with $80 \mathrm{~kg}$ $\mathrm{N} / \mathrm{ha}$ and harvesting was done the following spring. 
Tiller height and net photosynthesis were measured using a 3 metre ruler and LICOR LI-6400 portable photosynthesis system respectively; 12 - 16 weeks after the treatment was applied. Photosynthesis was measured from ten youngest expanded leaf blades per lysimeter. Pre-treatment measurements were taken to ensure that differences in the course of the experiment were as a resulted from the treatments. Harvested biomass was dried in an oven at $65-70^{\circ} \mathrm{C}$ for $48 \mathrm{~h}$, weighed, crushed and milled through a fine wire mesh. The milled samples were then analysed for Al, Fe, K, S and Si composition using ICP-OES (Thermo Scientific, ICAP 6000) after nitric acid digestion. Means of all data obtained were subjected to ttest using SPSS 15 (SPSS Inc., Chicago, USA).

\section{Results}

Reed canary grass tillers grown in HWC lysimeters were 30 and $23 \%$ taller than those in LWC lysimeters (P $\geq 0.001, \mathrm{P}=0.003$ ) in 2009 and 2010, respectively. On the other hand, net photosynthesis was higher in LWC grasses, although this was significant only in $2009(\mathrm{P}=0.04)$. There were no differences between the treatments in 2008.

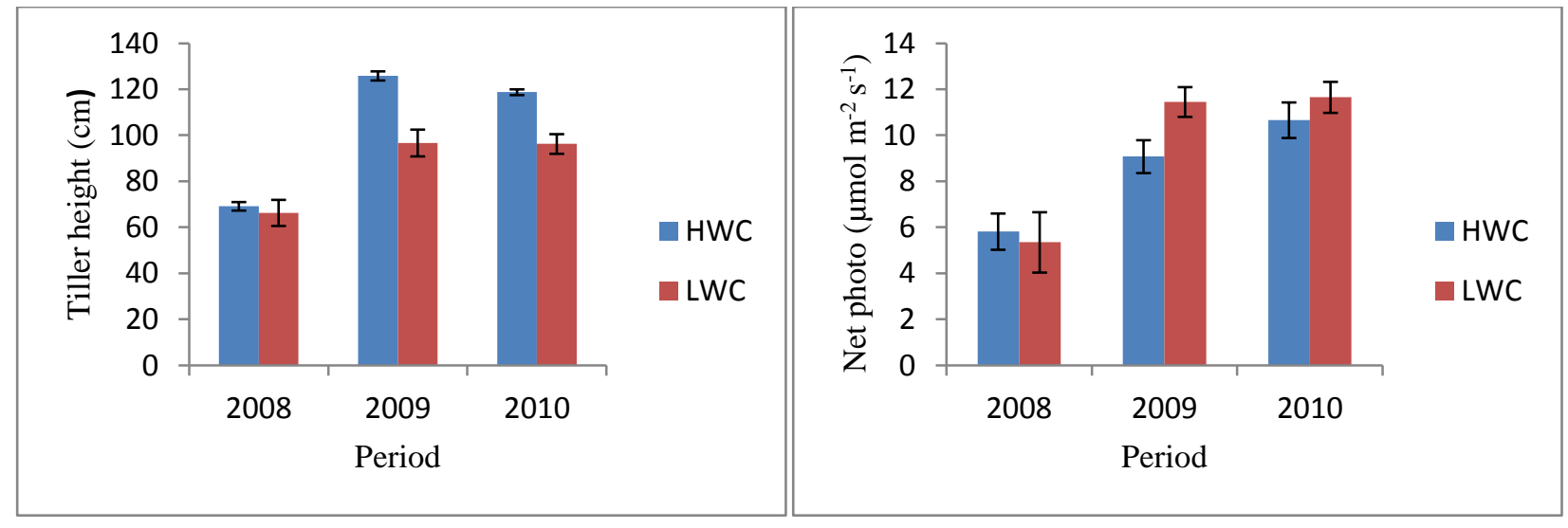

Figure 1. Tiller height and net photosynthesis of reed canary grass grown in acid sulphate soils with low and high water contents. Error bars show standard errors of means.

Dry matter yields in spring 2009 were almost the same in both treatments, but in 2010 and 2011, grasses in the HWC treatment yielded $43 \%$ and $37 \%$ more than those in LWC (P $\leq 0.001)$, respectively. In both 2010 and 2011, spring harvested material contained more Al, K, S and Si in the LWC treatment than in HWC, significantly so in the later year. Concentrations of Fe were higher in HWC treatment in 2009 and 2010, but not significantly so.

Table 1. Biomass yield and element composition of reed canary grass grown in low and high water table acid sulphate soil in lysimeters. 


\begin{tabular}{ccccccc} 
Year/ Treatment & Biomass yield(t/ha) & $\begin{array}{c}\mathrm{Al} \\
(\mathrm{mg} / \mathrm{kg})\end{array}$ & $\begin{array}{c}\mathrm{Fe} \\
(\mathrm{mg} / \mathrm{kg})\end{array}$ & $\begin{array}{c}\mathrm{K} \\
(\mathrm{mg} / \mathrm{kg})\end{array}$ & $\begin{array}{c}\mathrm{S} \\
(\mathrm{mg} / \mathrm{kg})\end{array}$ & $\begin{array}{c}\mathrm{Si} \\
(\mathrm{mg} / \mathrm{kg})\end{array}$ \\
\hline 2009 & & & & & & \\
HWC & 11.3 & 24.8 & 75.5 & 8106 & 1928 & 281 \\
LWC & 11.3 & 28.8 & 67.6 & 9448 & 1823 & 221 \\
P-value & & & & $*$ & & \\
& & & & & & \\
2010 & 20.1 & 7.3 & 48.5 & 7476 & 1861 & 386 \\
HWC & 14.1 & 12.1 & 44.3 & 12122 & 2313 & 504 \\
LWC & $* *$ & & & & & \\
P-value & & & & & & \\
& & & & & & \\
2011 & 16.0 & 11.2 & 55.3 & 7564 & 2128 & 355 \\
HWC & 11.7 & 20.8 & 78.0 & 12258 & 2641 & 366 \\
LWC & $* *$ & $*$ & & $* *$ & $*$ & \\
P-value & & & & & &
\end{tabular}

\section{Discussion}

High water table in a.s.soils affected growth, biomass quantity and quality of RCG. Tillers growing in HWC lysimeters were taller than those of the LWC lysimeters. LWC lysimeters not only contained oxidized a.s.soil, but also had insufficient water supply compared to HWC lysimeter. RCG is well adapted to wet conditions and the "drought" conditions in the LWC lysimeters could have affected growth and other physiological processes. Drought stress affects leaf expansion (Tardieu et al. 1999). This study reveals that drought conditions in the LWC lysimeters also reduced growth of RCG and these modifications could be due to self adaptive mechanism in these conditions (Qaderi et al. 2006).

The thicker, greener nature of the leaves in the LWC treatment suggest that the plants had more chlorophyll than the HWC plants which could account for their higher net photosynthesis rate. This result confirms that drought stress in RCG affects leaf expansion to a larger extent than photosynthesis (Tardieu et al. 1999), However, the results obtained contradict those of Shurpali et al. (2009) and Bota et al. (2004) that low soil water availability limits photosynthetic activity. Magnesium may also have been more available in the oxidized soil than in HWC treatment, contributing to higher chlorophyll content.

In both treatments, biomass yields exceeded the 6-8 t/ha reported by Pahkala et al. (2008) for northern conditions indicating that the conditions in the lysimeters were conducive to good growth, in spite of the low $\mathrm{pH}$ and low water availability of LWC treatment. The $\mathrm{pH}$ of top $20 \mathrm{~cm}$ of soil was 6.4 while the lower horizons had a pH of 3.8-4.2 (Virtanen et al. 2010). Furthermore, the high biomass productivity shows that RCG is not inhibited by low $\mathrm{pH}$ in a.s. soils as some other species are (Gilker et al. 2002). The significantly higher biomass from HWC lysimeters was as a result of increased tiller number and height, leaf size and number compared to the LWC lysimeters.

The soil conditions greatly influenced the element composition of the harvested dry biomass. Silica levels in RCG were shown to be greatly influenced by soil type and its Si content (Pahkala et al. 1996). The higher concentrations of $\mathrm{Al}, \mathrm{Fe}, \mathrm{K}, \mathrm{S}$ and $\mathrm{Si}$ of the LWC treatment indicate higher availability of these elements in the soil (Virtanen et al. 2010). Low concentrations of these 
elements are favoured in bioenergy crops since high concentrations cause slagging and corrosion when they are burned in combine heat and power plants. Raising the water table in an a.s.soil not only increases $\mathrm{pH}$, it also lowers concentrations of metals such as $\mathrm{Al}$ and other elements that will affect the plant and its use as a bioenergy crop.

\section{Conclusion}

Reed canary grass, an established bioenergy crop, grows well in acid sulphate soils and can perform better when the water table is raised to reduce acidity and prevent environmental hazards. RCG grown in high water content a.s.soil grew taller and produced higher biomass with good quality for use in energy production. This could serve as management option and a solution to the problems cause by a.s.soils and same time defusing the tension of food vs bioenergy crop production on arable land.

\section{References}

Aström, M., Sundtröm, R., Holmberg, M. and Storberg, K. 2005. pH streams in western Finland - a perspective for the Middle Ages into the mid 21st century. Agriculture and Food Science 14: 5-13.

Bota, J., Medrano, H. \& Flexas, J. 2004. Is photosynthesis limited by decreased Rubisco activity and RuBP content under progressive water stress? New Phytologist 162: 671-681.

Braun, J. von, Rosegrant, M.W., Pandya-Lorch, R., Cohen, M.J., Cline, S.A., Brown, M.A. and Soledad Bos, M. 2005. New risks and opportunities for food security. Scenario analyses for 2015 and 2050. International Food Policy Research Institute 2020 Discussion Paper 39, 32 p. IFPRI, Washington, DC.

Dent, D. 1986. Acid Sulphate Soils: A Baseline for Research and Development. ILRI Publication 39, Wageningen.

Gilker, R.E., Weil, R.R., Krizek, D.T. and Momen, B. 2002. Eastern gammagrass root penetration in adverse subsoil conditions. Soil Science Society American Journal 66: 931-938.

Hudd, R. and Leskelä, A. 1998. Acidification-induced species shifts in coastal fisheries off the river Kyrönjoki, Finland: a case study. Ambio 27: 535-53.

Lewandowski, I., J.M.O. Scurlock, E. Lindvall and M. Christou, 2003. The development and current status of perennial rhizomatous grasses as energy crops in the US and Europe. Biomass and Bioenergy 25: 335-361.

Mokma DL, Yli-Halla M, Hartikainen H (2000) Soils in a young landscape on the coast of southern Finland. Agricultural and Food Science in Finland 9, 291-302.

Pahkala, K. and Pihala, M. 2000. Different plant parts as raw material for fuel and pulp production. Industrial Crops and Products 11: 119-128

Pahkala, K., Mela, T., Hakkola, H., Jarvi, A. And Virajari, P. 1996. Production and use of agofibre in Finland. Finla report of the study. Part 1. Production of agrofibre crops: agronomy and varieties, 84pp.

Pahkala, K., Aalto, M., Isolahti, M., Poikola, J., \& Jauhiainen, L. 2008. Large-scale energy grass farming for power plants - A case study from Ostrobothnia, Finland. Biomass Bioenerg. 32: 1009-1015.

Qaderi, M.M, Kurepin, L.V. \& Reid, D.M. 2006 Growth and physiological responses of canola (Brassica napus) to three components of global climate change: temperature, carbon dioxide and drought. Physiologia Plantarum 128: 710-721.

Robertson, G.P., Virginia, D.H., Otto, C. D. 2008. Sustainable biofuels redux. Science 322: 49-50. 
Shurpali, N.J., Hyvönen, N.P., Huttunen, J.T., Clement, R.J., Reichstein, M., Nykänen, N., Biasi, C., \& Martikainen, P. J. 2009. Cultivation of a perennial grass for bioenergy on a boreal organic soil - carbon sink or source? Global Change Biology Bioenergy 1: 35-50.

Tardieu, F., Granier, C. \& Muller, B. 1999. Modelling leaf expansion in a fluctuating environment: are changes in specific leaf area a consequence of changes in expansion rate? New Phytologist 143: 33-43.

Vaino-Mattila, B., Ginström, T., Haaranen, T., Luomanperä, S., Lähdetie, P., Oravuo, M., Pietola, K., Suojanen, M., Virolainen, J., Knuutila, k., and Ovaska, S. 2005. Future of crop production in Finland (in Finnish). 44p., Report 2005: 15, Ministry of Agriculture, Helsinki.

Virtanen, S. Simojoki, A., and Yli-Halla, M. 2010. Monolithic lysimeters as tools to study the composition of pore and drainage waters responding to high water table in boreal acid sulphate soil. Proceedings of the 19th World Congress of Soil Science, Soil Solutions for a Changing World. 1 - 6 August 2010, Brisbane, Australia.

Ward, N.J., Sullivan, L.A. and Bush, R.T. 2004. The response of partially oxidised acid sulphate soil materials to anoxia. Australian Journal of Soil Resources 42: 514-525.

Yli-Halla, M., Puustinen, M. and Koskiaho, J. 1999. Area of cultivated acid sulphate soils in Finland. Soil Use Management 15: 62-67.

Yli-Halla, M., Mokma, D. L., Wilding, L. P., Drees, L. R. 2008. Morphology, Genesis and Classification of Acid Sulphate Soils of Finland. In ' Proceedings of the Joint Conference of the 6th International Acid Sulfate Soil Conference and the Acid Rock Drainage Symposium'(Ed C Lin, S Huang, Y Li), pp. 224-228. (Guangdong Press Group: Guangzhou). 